\title{
Mitral valve prolapse-a pervasive condition of uncertain etiology
}

\author{
MARJORIE M. SIEBERT, DO \\ SHELDON KULE, DO
}

Mitral valvular prolapse is a common valvular abnormality, with a incidence of $4 \%$ to $15 \%$. Familial incidence and clinical association and pathogenesis are discussed.

Mitral valve prolapse (MVP), the most commonly diagnosed valvular abnormality in human beings, ${ }^{1}$ has attracted the attention of some of the greatest names in medicine-Osler, Lewis, DaCosta, Levine, and White, to name a few. ${ }^{2}$ In 1836 , Williams ${ }^{3}$ described a bellow-like sound that occurred in nervous palpitations. This sound, he wrote, is a consequence of a slight regurgitation of blood that accompanies imperfect action of the valves and that is generally "observed in hysteria, females, and hypochondriasis."

\section{Incidence}

Since Williams' description (probably the first) of MVP, there has been mounting fascination with the varying frequency of this condition. Savage and associates ${ }^{1}$ cited an incidence of $4 \%$ to $17 \%$ in the literature, while in their own Framingham study 1 of 2,224 men and 2,743 women, M-mode echocardiography showed age-dependent ranges of 0.7 to $4.4 \%$ male incidence and 1.4 to $17 \%$ female incidence. In another phonocardiographic and echocardiographic study ${ }^{4}$ of 100 asymptomatic young women, the incidence of MVP was $10 \%$.

\section{Familial association}

Many studies also reported familial incidence. Stannard and colleagues ${ }^{5}$ found auscultory evidence of MVP in one family of three sisters and another of two sisters. Weiss and coauthors ${ }^{6}$ studied 17 index cases and found echocardiograms consistent

with MVP in 27 of 57 first-degree relatives; transmission was to both sexes, but primarily to female subjects. Autosomal dominant inheritance was first proposed by Shell and associates ${ }^{-}$after phonocardiographic studies of 23 family members in four index cases. Using M-mode echocardiography, Pader $^{8}$ found that a female patient, her mother, and her grandmother all had MVP. This author concluded that MVP has an autosomal dominant pattern, with a sex-dependent mode of expression. The Framingham study found MVP in 9\% of offspring of subjects with MVP, with four times as many cases appearing in females as in males. ${ }^{1}$

\section{Clinical associations and pathogenesis}

Although some patients are asymptomatic, MVP has been proposed to be associated with a number of conditions, including atrial septal defect, ${ }^{9}$ Marfan's syndrome, ${ }^{10}$ Ehlers-Danlos syndrome, ${ }^{11}$ pectus excavatum, ${ }^{12}$ straight back, ${ }^{13}$ scoliosis, ${ }^{14}$ von Willebrand's syndrome; ${ }^{15}$ muscular dystrophy, ${ }^{16}$ left ventricuar dysfunction, ${ }^{17}$ osteogenesis imperfecta $\operatorname{tarda},{ }^{18}$ pseudoxanthoma elasticum; ${ }^{19}$ pulmonary hypertension, ${ }^{20}$ right ventricular enlargement, ${ }^{20}$ hypomastia, ${ }^{21}$ and dermal arches. ${ }^{22-24}$

Two main unifying theories have been proposed to explain most or all of these associations. The first describes MVP as a developmental defect not merely of the heart valve but of all connective tissue, and even of the entire mesenchymal primordial substance. ${ }^{9,10,15,17,19,21,22}$ Affected tissues in all of these disorders are derived embryologically from mesenchymal cell origins.

The other theory proposes that MVP mostly is a phenomenon produced by altered geometry of the heart, which can be produced directly by atrial septal defect, left ventricular dysfunction, and right ventricular enlargement ${ }^{11-14,16}$. The geometry of 
the heart is altered indirectly via the musculoskeletal system in straight back, Marfan's syndrome, Ehlers-Danlos syndrome, pectus excavatum, scoliosis, and muscular dystrophy. It also is altered indirectly in pulmonary hypertension by the lungs and vascular bed.

\section{Hypomastia}

Rosenberg and coresearchers ${ }^{21}$ hypothesized MVP to correlate with hypomastia, because both the mitral valve and mammary gland derive from the mesenchyma, and both differentiate during the sixth week of fetal life. Their study surveyed 27 women with primary hypomastia who presented for augmentation mammoplasty. Postpartum or involutional atrophy patients and postmastectomy patients were excluded from the study. Echocardiography demonstrated MVP in 13 of the 27 women $(48 \%)$ in the study group, compared with 2 of the $33(6 \%)$ healthy staff members who comprised the control group. A cross-study demonstrated hypomastia (breast size $\leqslant 200 \mathrm{cc}$ ) in 17 of 28 women $(61 \%)$ with known MVP; 13 women $(46 \%)$ in this group were found to have one or more skeletal abnormalities (pectus excavatum, scoliosis, or straight back). These findings lend support to the systemic development defect theory of MVP.

\section{Dermal arches}

Schwartz and coworkers ${ }^{23}$ found an increased prevalence in dermal arches in symptomatic patients with MVP, while two subsequent studies had contrary findings. Tay and associates ${ }^{22}$ found no significant difference in the incidences of dermal arches between an MVP group of school children in Singapore with a control group of children. Kramer-Fox and coworkers ${ }^{24}$ surveyed 42 subjects with diagnosed MVP, 140 first-degree relatives (48 of whom had MVP), and a control group of their spouses and hospital workers. No significant difference was found in the occurrence of dermal arches among the MVP subjects, the relatives, and the control group.

\section{Atrial septal defect}

In an analysis of 200 patients with auscultory evidence of MVP, Pocock and Barlow ${ }^{9}$ found 17 (9\%) with secundum-type defects of the atrial septum. Fourteen of these 17 underwent surgical closure. Postoperatively, the murmurs associated with MVP changed sporadically; three disappeared completely, two intensified, and nine did not change. Citing the high incidence of atrial septal defect, the authors proposed an embryologic basis for MVP. The fact that the auscultory findings did not improve with surgical repair was not considered.
They believed that the posterior location of these secundum-type defects would have little effect on the more anteriorly positioned mitral valve.

\section{Ventricular changes}

Garcia-Dorado and coauthors ${ }^{20}$ suggested that changes in left ventricular volume and the geometry of the heart caused MVP in patients with atrial septal defect, pulmonary hypertension, and hypertrophic cardiomyopathy. They evaluated echocardiograms of 176 patients with symptoms of pulmonary hypertension after epidemic poisoning with rapeseed oil. This produced pulmonary hypertension by diffuse vasculitis and vasoconstriction, which led to right ventricular hypertrophy.

The patients were correlated by right ventricle size and the incidence of MVP. Those with borderline or normal-sized ventricles had a $9 \%$ incidence of MVP. In those with moderately enlarged ventricles, the incidence was $30 \%$, and those with severe ventricular enlargement had an incidence of $56 \%$. Follow-up echocardiograms were obtained for 12 patients with severe-to-moderate right ventricular hypertrophy on initial study. Of these, eight had had the ventricle size return to normal. Three of these eight had demonstrated MVP on the original echocardiogram, but all three were normal at follow up. These authors proposed that the altered right ventricular geometry, rather than a developmental defect, accounted for MVP in these patients.

Yoshimitsu and coworkers ${ }^{16}$ attempted to determine whether the frequent incidence of MVP in progressive muscular dystrophy was due to the changes in left ventricular function or to the altered structure of the thorax. Sixty-nine patients with muscular dystrophy were classified into three groups: Group 1 included 38 persons without MVP; group 2 included 11 persons with MVP confirmed by M-mode echocardiography; and group 3 included 16 patients with MVP on both M-mode and twodimensional echocardiography.

Left ventricular function, as evaluated by systolic time intervals, did not differ for the three groups. Straight or lordotic spines were found in $32.3 \%, 100 \%$, and $93.8 \%$ of groups 1,2 , and 3 , respectively. Inversely, the incidence of MVP in cases with thoracic kyphosis was $4.8 \%$, with straight spines $66.7 \%$, and with lordotic thoracic spines $77.8 \%$.

It was concluded that thoracic geometry, rather than a defect in the myocardium, was the causative agent for MVP in muscular dystrophy. The authors further theorized that all cases of MVP, whether geometric or developmental, cannot be assumed to be from the same cause. Earlier, Yoshimitsu had conducted an unpublished study 


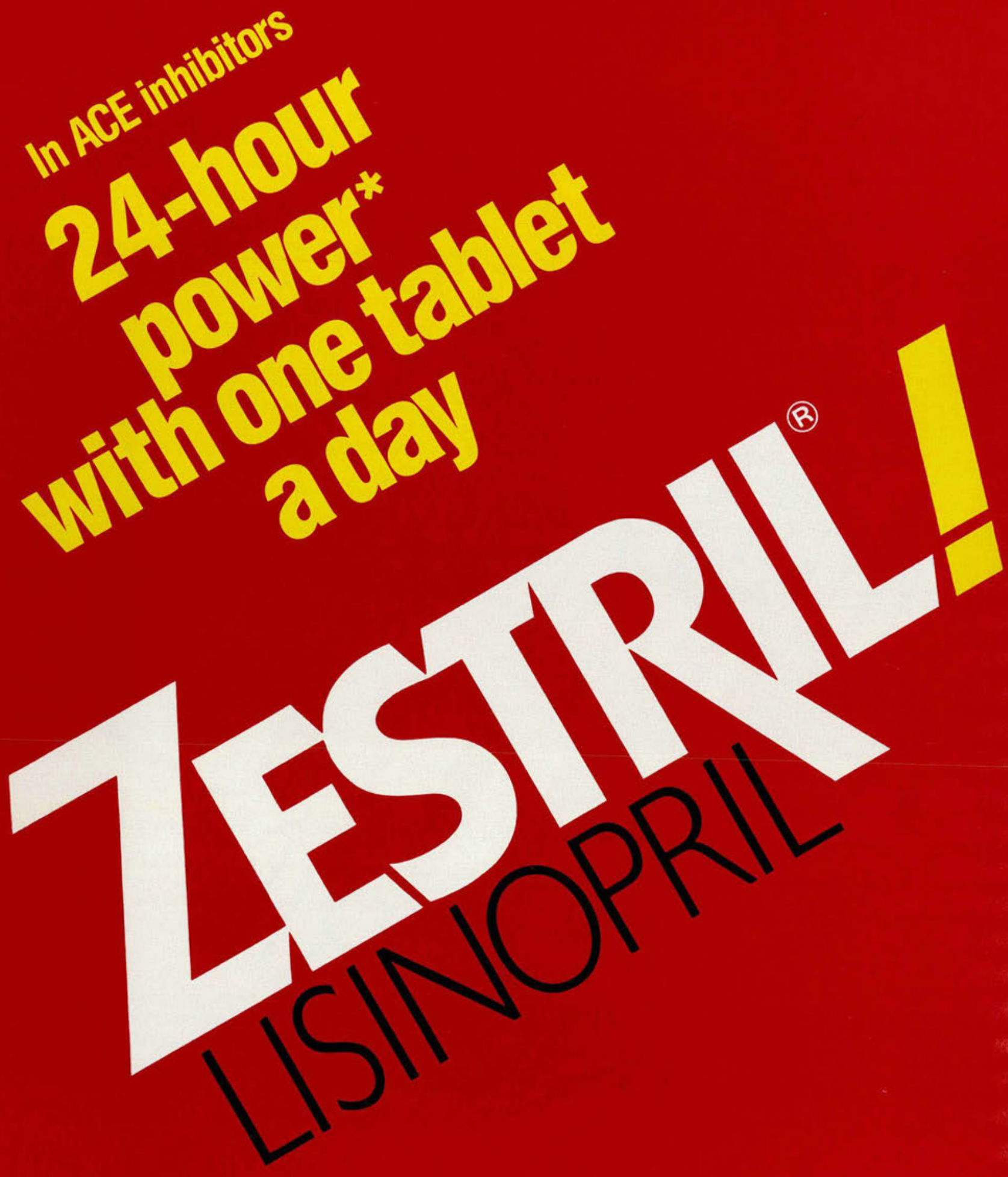

Zestril: The long-acting ACE inhibitor

Zestril achieves 24-hour blood pressure control with a half-life of 12 hours. Angiotensin converting enzyme (ACE) inhibition ${ }^{+}$is long lasting with Zestrilsustained 24 hours after a single dose. ${ }^{2-4}$ 


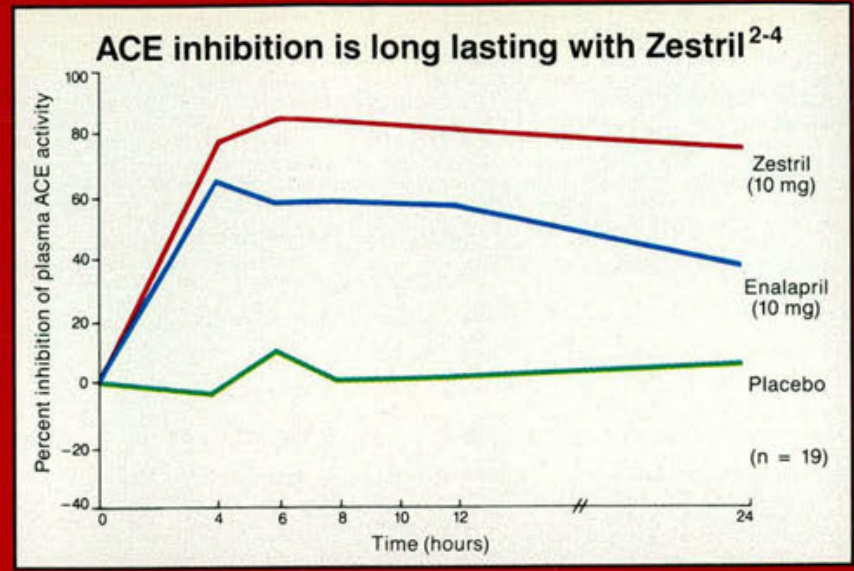

†In pharmacodynamic studies (utilizing $10 \mathrm{mg}$ of enalapril and lisinopril), ACE inhibition was significantly correlated to plasma renin activity and fall in diastolic blood pressure in normal volunteers. ${ }^{3}$

- adapted from Ajayi et al, p 424²

The clinical significance of pharmacodynamic differences among ACE inhibitors observed in normal volunteers has not been determined in hypertensive patients.

\section{Zestril: Hypertensive patients start and stay at one tablet a day}

A single tablet of Zestril reduces blood pressure for 24 hours ${ }^{1}-$ unlike other ACE inhibitors, which may have to be increased to b.i.d. ${ }^{5}$ or t.i.d. ${ }^{6}$ dosing in some patients. The predictable once-daily dosage of Zestril enhances patient compliance and cost-effectiveness.

\section{Zestril: 24-hour blood pressure control that's easy to live with}

Zestril shares the low incidence of side effects characteristic of ACE inhibitors. Additionally, rash or taste disturbance is rarely seen with Zestril. What's more, Zestril is not metabolized by the liver. It is absorbed as the active drug and does not require bioactivation ${ }^{7}-$ as needed with prodrugs such as enalapril. ${ }^{\ddagger 5}$ Absorption of Zestril is unaffected by food..$^{8}$

Evaluation of the hypertensive patient should always include assessment of renal function. (See Dosage and Administration.)

Angioedema has been reported with ACE inhibitors, including Zestril. (See Warnings.)

$1988 \mathrm{ICl}$ Americas Inc.

he antihypertensive effect may diminish at the end f the dosing interval.

linical significance has not been determined in ypertensive patients. 
ZESTRIL ${ }^{*}$ (lisinopril)

INDICATIONS AND USAGE. Zestril is indicated for the treatment of hypertension. It may be used alone as initial therapy or concomitantly with other classes of antihypertensive agents. In using Zestril, consideration
should be given to the fact that another angiotensin converting enzyme inhibitor, captopril, has caused agranulocytosis, particularly in patients with renal impairment or collagen vascular disease, and that available data are insulficient to show that Zestril does not have a similar risk. (See WARNINGS.) CONTRAINDICATIONS. Zestril is contraindicated in patients who are hypersensitive to this product. WARNINGS. Angioedema: Angioedema of the face, extremities, lips, tongue, glottis and/or larynx has been reported in patients treated
with angiotensin converting enzyme inhibitors, including Zestril. In such cases. Zestril should be promptly with angiotensin converting enzyme inhibitors, including Zestril. In such cases. Zestril should be promptly
discontinued, and the patient carefully observed until the swelling disappears. In instances where swelling has been confined to the face and lips the condition has generally resolved without treatment, although antihistamines have been useful in relieving symptoms. Angioedema associated with laryngeal edema may
be fatal. Where there is involvement of the tongue, glottis or larynx, likely to cause airway obstruction, appropriate therapy, eg, subcutaneous epinephrine solution 1:1000 $(0.3 \mathrm{~mL}$ to $0.5 \mathrm{~mL})$ should be promptly administered. (See ADVERSE REACTIONS.) Hypotension: Excessive hypotension was rarely seen in uncornplicated hypertensive patients but is a possible consequence of use with Zestril in salt/volume-depleted persons, such as those treated vigorously with diuretics or patients on dialysis. (See PRECAUTIONS, Drug Interactions
and ADVERSE REACTIONS.) In patients with severe congestive heart failure, with or without associated renal insutficiency excessive hypotension has been observed and may be associated with oliguria and/or progressive azotemia, and rarely with acute renal failure and/or death. Because of the potential fall in blood pressure in these patients, therapy should be started under very close medical supervision. Such patients should be followed closely for the first two weeks of treatment and whenever the dose of Zestril and/or diuretic is increased. Similar considerations apply to patients with ischemic heart or cerebrovascular disease in whom an excessive tall in blood pressure could result in a myocardial infarction or cerebrovascular accident, It hypotension occurs. the patient should be placed in supine position and, if necessary, receive an intravenous infusion of normal saline. A transient hypotensive response is not a contraindication to further doses which usually can be given without difficulty once the blood pressure has increased after volume expansion. Neutropenia/Agranulocytosis: Another angiotensin converting enzyme inhibitor, captopril, has been shown to cause agranulocytosis and bone marrow depression, rarely in uncomplicated patients but more frequently in patients with renal impairment especially if they also have a collagen vascular disease. Available data from clinical trials of Zestril are insufficien counts in patients with collagen vascular disease and renal disease should be considered. PRECAUTIONS. General. Impaired Renal Function: As a consequence of inhibiting the renin-angiotensin-aldosterone system, changes in renal function may be anticipated in susceptible individuals. In patients with severe congestive heart failure whose renal function may depend on the activity of the renin-angiotensin-aldosterone system treatment with angiotensin converting enzyme inhibitors, including Zestril, may be associated with oliguria and/or progressive azotemia and rarely with acute renal failure and/or death. In hypertensive patients with unilateral or bilateral renal artery stenosis, increases in blood urea nitrogen and serum creatinine may occur. Experience with another angiotensin converting enzyme inhibitor suggests that these increases are usually reversible upon discontinuation of Zestril and/or diuretic therapy. In such patients, renal function should be monitored during the first few weeks of therapy. Some hypertensive patients with no apparent pre-existing renal vascular disease have developed increases in blood urea nitrogen and serum creatinine, usually minor occur in patients with pre-existing renal impairment. Dosage reduction of Zestril and/or discontinuation o the diuretic may be required. Evaluation of the hypertensive patient should always include assessment of renal function. (See DOSAGE AND ADMINISTRATION.) Hyperkalemia: In clinical trials hyperkalemia (serum potassium greater than $5.7 \mathrm{mE} / \mathrm{L}$ ) occurred in approximately $2.2 \%$ of hypertensive patients and $4.0 \%$ of patients with congestive heart failure. In most cases these were isolated values which resolved despite continued therapy. Hyperkalemia was a cause of discontinuation of therapy in approximately $0.1 \%$ of hypertensive patients. concomitant use of potassium-sparing diuretics, potassium supplements and/or potassium-containing sal substitutes, which should be used cautiously, if at all, with Zestril. (See Drug Interactions.) Surgery/Anesthesia: In patients undergoing major surgery or during anesthesia with agents that produce hypotension, Zestril may sidered to be due to this mechanism, it can be corrected by volume expansion. Information for Patients. Angioedema: Angioedema, including laryngeal edema, may occur especially following the first dose of Zestril. Patients should be so advised and told to report immediately any signs or symptoms suggesting angioedema (Swelling of face, extremities, eyes, lips, tongue, difficulty in swallowing or breathing) and to take no more
drug until they have consulted with the prescribing physician. Symptomatic Hypotension: Patients should be cautioned to report lightheadedness especially during the first few days of therapy. If actual syncope occurs, the patient should be told to discontinue the drug until they have consulted with the prescribing physician. All patients should be cautioned that excessive perspiration and dehydration may lead to an excessive fall in blood pressure because of reduction in fluid volume. Other causes of volume depletion such as vomiting Hyperkalemia: Patients should be told not to use salt substitutes containing potassium without consultin their physician. Neutropenia: Patients should be told to report promptly any indication of infection (eg, sore being treated with Zestril is warranted. This information is intended to aid in the safe and effective use of this medication. It is not a disclosure of all possible adverse or intended effects. Drug Interactions. Hypowas recently instituted may occasionally experience an excessive reduction of blood pressure after initiation of therapy with Zestril. The possibility of hypotensive effects with Zestril can be minimized by either discontinuing the diuretic or increasing the salt intake prior to initiation of treatment with Zestril. If it is necessary to continue the diuretic, initiate therapy with Zestril at a dose of $5 \mathrm{mg}$ daily, and provide medical supervision after the initial dose for at least two hours and until blood pressure has stabilized for at least an additional hour. (See
WARNINGS, and DOSAGE AND ADMINISTRATION.) When a diuretic is added to the therapy of a patient receiving Zestril, an additional antihypertensive effect is usually observed. Studies with ACE inhibitors in combination with diuretics indicate that the dose of the ACE inhibitor can be reduced when it is given with a diuretic. (See where the antihypertensive effects of Zestril alone were compared to Zestril given concomitantly with indomethacin, the use of indomethacin was associated with a reduced effect, although the difference between the two regimens was not significant. Other Agents: Zestril has been used concomitantly with nitrates and/or digoxin without evidence of clinically significant adverse interactions. No clinically important pharmacokinetic interactions occurred when Zestril was used concomitantly with propranolol or hydrochlorothiazide. The
presence of food in the stomach does not alter the bioavailability of Zestril. Agents Increasing Serum Potassium: prestril attenuates potassium loss caused by thiazide-type diuretics. Use of Zestril with potassium-sparing diuretics (eg. spironolactone, triamterene or amiloride), potassium supplements, or potassium-containing diuretics (eg. Spironolactone, triamterene or amiloride), potassium supplements, or potassium-containing
salt substitutes may lead to significant increases in serum potassium. Therefore, if concomitant use of these agents is indicated because of demonstrated hypokalemia, they should be used with caution and with frequent monitoring of serum potassium. Carcinogenesis, Mutagenesis, Impairment of Fertility. There was no evidence of a tumorigenic effect when lisinopril was administered for 105 weeks to male and female rats at doses up to $90 \mathrm{mg} / \mathrm{kg} /$ day (about 56 times* the maximum recommended daily human dose) or when lisinopril was
administered for 92 weeks to (male and female) mice at doses up to $135 \mathrm{mg} / \mathrm{kg} /$ day (about 84 times maximum recommended daily human dose). "Based on patient weight of $50 \mathrm{Kg}$. Lisinopril was not mutagenic in the Ames microbial mutagen test with or without metabolic activation. It was also negative in a forward mutation assay using Chinese hamster lung cells. Lisinopril did not produce single strand DNA breaks in an in vitro ala ine elution rat hepatocyte assay. In addition, lisinopril did not produce increases in chromosoma aberrations in an in vitro test in Chinese hamster ovary cells or in an in vivo study in mouse bone marrow. $300 \mathrm{mg} / \mathrm{kg} / \mathrm{day}$ of lisinopril. Pregnancy. Pregnancy Category C: Lisinopril was not teratogenic in mice treated on days $6-15$ of gestation with up to $1,000 \mathrm{mg} / \mathrm{kg} / \mathrm{day}$ ( 625 times the maximum recommended human dose).
There was an increase in fetal resorptions at doses down to $100 \mathrm{mg} / \mathrm{kg}$; at doses of $1,000 \mathrm{mg} / \mathrm{kg}$ this was There was an increase in fetal resorptions at doses down to $100 \mathrm{mg} / \mathrm{kg}$; at doses of $1,000 \mathrm{mg} / \mathrm{kg}$ this was
prevented by saline supplementation. There was no fetotoxicity or teratogenicity in rats treated with up to prevented by saline supplementation. There was no fetotoxicity or teratogenicity in rats treated with up to
$300 \mathrm{mg} / \mathrm{kg} / \mathrm{day}$ ( 188 times the maximum recommended dose) of lisinopril at days $6-17$ of gestation. In rats receiving lisinopril from day 15 of gestation through day 21 postpartum, there was an increased incidence
in pup deaths on days $2-7$ postpartum and a lower average body weight of pups on day 21 postpartum. The in pup deaths on days $2-7$ postpartum and a lower average body weight of pups on day 21 postpartum. The
increase in pup deaths and decrease in pup weight did not occur with maternal saline supplementation. increase in pup deaths and decrease in pup weight did not occur with maternal saline supplementation.
Lisinopril, at doses up to $1 \mathrm{mg} / \mathrm{kg} / \mathrm{day}$, was not teratogenic when given throughout the organogenic period in saline supplemented rabbits. Saline supplementation (physiologic saline in place of tap water) was used dosage level. The rabbit has been shown to be extremely sensitive to angiotensin converting enzyme inhibitor (captopril and enalapril) with maternal and fetotoxic effects apparent at or below the recommended therapeutic dosage levels in man. Fetotoxicity was demonstrated in rabbits by an increased incidence of fetal resorptions
at a dose of lisinopril at $1 \mathrm{mg} / \mathrm{kg} / \mathrm{day}$ and by an increased incidence of incomplete ossification at the lowes dose tested ( $(0.1 \mathrm{mg} / \mathrm{kg} / \mathrm{day})$. By whole body autoradiography, radioactivity was found in the placenta following and well-controlled studies in pregnant women. Zestril should be used during pregnancy only if the potentia benefit justifies the potential risk to the fetus. Nursing Mothers: Milk of lactating rats contains radioactivity
following administration of ${ }^{14} \mathrm{C}$ lisinopril. It is not known whether this drug is excreted in human milk.
Because many drugs are excreted in human milk, caution should be exercised when Zestril is given to a nursing Zestril has been found to be generally well tolerated in controlled clinical trials involving 2003 patients an Zestrii has been found to be generally weil tolerated in controlled clinical trials involving 2003 patients and
subjects. The most frequent clinical adverse experiences in controlled trials were dizziness $(6.3 \%)$, headache subjects. The most frequent clinical adverse experiences in controlled trials were dizziness $(6.3 \%)$, headache
$(5.3 \%)$, fatigue $(3.3 \%)$, diarrhea $(3.2 \%)$, upper respiratory symptoms $(3.0 \%)$, and cough $(2.9 \%)$, all of which were more frequent than in placebo-treated patients. For the most part, adverse experiences were mild an transient in nature. Discontinuation of therapy was required in $6.0 \%$ of patients. In clinical trials, the overa frequency of adverse experiences could not be related to total daily dosage within the recommended therapeuti dosage range. For adverse experiences which occurred in more than $1 \%$ of patients and subjects treatec listed in the table below. Percent of Patients in Controlled Studies

\begin{tabular}{|c|c|c|c|}
\hline & $\begin{array}{c}\text { Zestril } \\
\text { ( } n=2003 \dagger) \\
\text { Incidence } \\
\text { (discontinuation) }\end{array}$ & $\begin{array}{c}\text { Zestril/Hydrochlorothiazide } \\
(n=644) \\
\text { Incidence } \\
\text { (discontinuation) }\end{array}$ & $\begin{array}{c}\text { Placebo } \\
\text { (n=207) } \\
\text { Incidence }\end{array}$ \\
\hline $\begin{array}{l}\text { Dizziness } \\
\text { Headache } \\
\text { Fatigue } \\
\text { Diarrhea } \\
\text { Upper Respiratory Symptoms } \\
\text { Cough } \\
\text { Nausea } \\
\text { Hypotension } \\
\text { Rash } \\
\text { Orthostatic Effects } \\
\text { Asthenia } \\
\text { Chest Pain } \\
\text { Vomiting } \\
\text { Dyspnea } \\
\text { Dyspepsia } \\
\text { Paresthesia } \\
\text { Impotence } \\
\text { Muscle Cramps } \\
\text { Back Pain } \\
\text { Nasal Congestion } \\
\text { Decreased Libido } \\
\text { Vertigo }\end{array}$ & $\begin{array}{l}6.3(0.6) \\
5.3(0.2) \\
3.3(0.2) \\
3.2(0.3) \\
3.0(0.0) \\
2.9(0.4) \\
2.3(0.3) \\
1.8(0.8) \\
1.5(0.4) \\
1.4(0.0) \\
1.3(0.4) \\
1.3(0.1) \\
1.3(0.2) \\
1.1(0.0) \\
1.0(0.0) \\
0.8(0.0) \\
0.7(0.2) \\
0.6(0.0) \\
0.5(0.0) \\
0.3(0.0) \\
0.2(0.1) \\
0.1(0.0)\end{array}$ & $\begin{array}{l}9.0(0.9) \\
4.3(0.5) \\
3.9(0.5) \\
2.6(0.3) \\
4.5(0.0) \\
4.5(0.8) \\
2.5(0.2) \\
1.6(0.5) \\
1.6(0.2) \\
3.4(0.2) \\
2.0(0.2) \\
1.2(0.2) \\
1.4(0.0) \\
0.5(0.2) \\
1.9(0.0) \\
2.0(0.2) \\
1.6(0.3) \\
2.8(0.6) \\
1.1(0.0) \\
1.2(0.0) \\
1.2(0.0) \\
1.1(0.2)\end{array}$ & $\begin{array}{l}1.9 \\
1.9 \\
1.0 \\
2.4 \\
0.0 \\
1.0 \\
2.4 \\
0.5 \\
0.5 \\
1.0 \\
1.0 \\
1.4 \\
0.5 \\
1.4 \\
0.0 \\
0.0 \\
0.0 \\
0.5 \\
1.4 \\
0.0 \\
0.0 \\
0.0\end{array}$ \\
\hline
\end{tabular}

fIncludes 420 patients treated for congestive heart failure who were receiving concomitant digitalis and diuretic therapy.

possibly drug related events reported in uncontrolled studies or marketing experience included: BODY AS AWHOLE: Chest discomfort, fever, flushing. CARDIOVASCULAR: Angina pectoris, orthostatic hypotension stipation, flatulence. METABOLISM: Gout. MUSCULOSKELETAL: Joint pain, shoulder pain. NERVOUS SY pharyngeal pain. UROGENITAL: Oliguria, progressive azotemia, acute renal failure. OTHER: Blurred vision
phis pruritus, un face, extremities, lips, tongue, glottis and/or larynx occurs, treatment with Zestril should be discontinuec and appropriate therapy instituted immediately. (See WARNINGS.) HYPOTENSION: In hypertensive patients cause of discontinuation of therapy in $0.5 \%$ of hypertensive patients. (See WARNINGS.) In patients witt
chents cause of discontinuation of therapy in $0.5 \%$ of hypertensive patients. (See WARN $1.0 \%$ of patients. Thes
congestive heart failure, hypotension occurred in $5.0 \%$ and syncope occurred in $1.0 \%$. adverse experiences were causes for discontinuation of therapy in $1.3 \%$ of these patients. Clinical Laborator
Test Findings. Serum Electrolytes: Hyperkalemia (See PRECAUTIONS.) Creatinine, Blood Urea Nitrogen Minor increases in blood urea nitrogen and serum creatinine, reversible upon discontinuation of therapy, wer observed in about $2.0 \%$ of patients with essential hypertension treated with Zestril alone. Increases wern more common in patients receiving concomitant diuretics and in patients with renal artery stenosis. (Se
PRECAUTIONS.) Reversible minor increases in blood urea nitrogen and serum creatinine were observed is approximately $9.1 \%$ of patients with congestive heart failure on concomitant diuretic therapy. Frequently these abnormalities resolved when the dosage of the diuretic was decreased. Hemoglobin and Hematocrit Small decreases in hemoglobin and hematocrit (mean decreases of approximately $0.4 \mathrm{~g} \%$ and $1.3 \mathrm{vol} \%$
respectively) occurred frequently in patients treated with Zestril but were rarely of clinical importance in patient: without some other cause of anemia. In clinical trials, less than $0.1 \%$ of patients discontinued therapy du to anemia. Other (Causal Relationship Unknown): Rarely, elevations of liver enzymes and/or serum bilirubi have occurred. Overall, $2.0 \%$ of patients discontinued therapy due to laboratory adverse experiences, principall
elevations in blood urea nitrogen $(0.6 \%)$, serum creatinine $(0.5 \%)$, and serum potassium $(0.4 \%)$. OVERDOSAAE elevations in blood urea nitrogen $(0.6 \%)$, serum creatinine $(0.5 \%)$, and serum potassium $(0.4 \%)$. OVERDOSAGE
The oral LD $L$ so of lisinopril is greater than $20 \mathrm{~g} / \mathrm{kg}$ in mice and rats. The most likely manifestation of over dosage would be hypotension, for which the usual treatment would be intravenous infusion of normal saline
solution. DOSAGE AND ADMINISTRATION. Initial Therapy: In patients with uncomplicated essential hyper tension not on diuretic therapy, the recommended initial dose is $10 \mathrm{mg}$ once a day. Dosage should be adjuste according to blood pressure response. The usual dosage range is $20-40 \mathrm{mg}$ per day administered in a singl
daily dose. The antihypertensive effect may diminish toward the end of the dosing interval regardless of the administered dose, but most commonly with a dose of $10 \mathrm{mg}$ daily. This can be evaluated by measuring bloo pressure just prior to dosing to determine whether satisfactory control is being maintained for 24 hours.
it is not, an increase in dose should be considered. Doses up to $80 \mathrm{mg}$ have been used but do not appea to give greater effect. If blood pressure is not controlled with Zestril alone, a low dose of a diuretic may b added. Hydrochlorothiazide, $12.5 \mathrm{mg}$ has been shown to provide an additive effect. After the addition of
diuretic, it may be possible to reduce the dose of Zestril. Diuretic Treated Patients: In hypertensive patient who are currently being treated with a diuretic, symptomatic hypotension may occur occasionally followin the initial dose of Zestril. The diuretic should be discontinued, if possible, for two or three days before beginnin therapy with Zestril to reduce the likelihood of hypotension. (See WARNINGS.) The dosage of Zestril shoul be adjusted according to blood pressure response. If the patient's blood pressure is not controlled with Zestri alone, diuretic therapy may be resumed as described above. If the diuretic cannot be discontinued, an initiza dose of $5 \mathrm{mg}$ should be used under medical supervision for at least two hours and until blood pressure has
stabilized for at least an additional hour. (See WARNINGS and PRECAUTIONS. Drug Interactions.) Concomitan administration of Zestril with potassium supplements, potassium salt substitutes, or potassium-sparin (1) In general, bloge of Zestril. Pharmacokinetic studies, however indicate that max concentration time curve (AUC) are doubled in older patients so that dosage adjustments should be mad with particular caution. Dosage Adjustment in Renal impairment. The usual dose of Zestril (10 mg) $3 \mathrm{mg} / \mathrm{dL}$ ). For patients with creatinine clearance $>10 \mathrm{~mL} / \mathrm{min} \leq 30 \mathrm{~mL} / \mathrm{min}$ (serum creatinine $\geq 3 \mathrm{mg} / \mathrm{dL}$ the first dose is $5 \mathrm{mg}$ once daily. For patients with creatinine clearance $<10 \mathrm{~mL} / \mathrm{min}$ (usually on hemodialysi the recommended initial dose is $2 . \mathrm{m}$
or to a maximum of $40 \mathrm{mg}$ daily.

\begin{tabular}{|lcc|}
\hline Renal Status & Creatinine-Clearance mL/min & Initial Dose mg/aay \\
\hline Normal Renal Function to Mild Impairment & $>30$ & 10 \\
Moderate to Severe Impairment & $\geq 10 \leq 30$ & 5
\end{tabular}

Moderate to Severe
Dialysis Patients

†Dosage or dosing interval should be adjusted depending on the blood press
Stuart Pharmaceuticals, Division of ICI Americas Inc., Wilmington, DE 19897.

REFERENCES: 1. Zestrilo (lisinopril) full prescribing information issued May 1988. 2. Ajayi AA, Campbell B Kelman AW, et al: Pharmacodynamics and population pharmacokinetics of enalapni and isinopni. Int J Clin Pham 4. Hodsman GP, Zabludowski JR, Zoccali C, et al: Enalapril (MK421) and its lysine analogue (MK521): A comparis of acute and chronic effects on blood pressure, renin-angiotensin system and sodium excretion in normal man. Br JC
Pharmacol 1984:17:233-241. 5. Physicians' Desk Reference, ed 42. Oradell, NJ, Medical Economics Co, 1988. Vasotec (enalapril maleate, MSD), pp 1406-1408.6. Physicians' Desk Reference, ed 42. Oradell, NJ, Medical Economics C (MK-521): Disposition in man. Br J Clin Pharmacol 1982; 14:357-362. 8. Mojaverian P. Rocci ML Jr. Viasses PH, el 
in which MVP was produced in six open-chested dogs by direct pressure of the left ventricle.

\section{Comment}

It is necessary to consider both the developmental and geometric concepts of MVP pathogenesis until further studies appear. Therefore, a patient with a systolic click and mid-to-late systolic murmur must be examined carefully for developmental anomalies. Patients with scoliosis, straight back, thoracic lordosis, or pectus excavatum should undergo echocardiography.

Although MVP usually has a benign course ${ }^{25}$ the possibility of arrhythmias, embolic phenomena, or endocarditis must be considered. As MVP receives more attention and more data are assembled, the pathogenesis will become apparent.

1. Savage DD, Garrison RJ, Devereux RB, et al: Mitral valve prolapse in the general population: 1. Epidemiologic features-The Framingham Study. Am Heart J 1983;106:571-576.

2. Partecchi CE: Historical beginning of the mitral valve prolapse syndrome. Am J Cardiol 1984;54:1165-1166.

3. Williams JC: Palpitations of the heart. London, Longman, Ress, Orme, and $\mathrm{Co}, 1836$.

4. Markiewicz W, Stoner J, London E, et al: Mitral valve prolapse in one hundred presumably healthy young females. Circulation 1976;53:464 473.

5. Stannard M, Sloman JG, Hare WS, et al: Prolapse of the posterior leaflet of the mitral valve: A clinical, familial, and geographic study. $\mathrm{Br}$ Med $J$ 1967;3:71-74

6. Weiss AN, Mimbs JW, Ludbrook PA, et al: Echocardiographic detection of mitral valve prolapse: Exclusion of false-positive diagnosis and determination of inheritance. Circulation 1975;52:1091-1096.

7. Shell WE, Walton JA, Clifford M, et al: The familial occurrence of the syndrome of mid-late systolic click and late systolic murmur Circulation 1969;39:327-337.

8. Pader E: The familial incidence of mitral valve prolapse: A report of three generations in one family. NY State J Med 1984;84:395-396.

9. Pocock WA, Barlow JB: An association between the billowing posterior mitral leaflet syndrome and congenital heart disease, particularly atrial septal defect. Am Heart $J$ 1971;81:720-722.

10. Brown OR, DeMots $\mathrm{H}$, Kloster FE, et al: Aortic root dilation and mitral valve prolapse in Marfan's syndrome: An echocardiographic study. Circulation 1975;52:652-657.

11. Brandt KD, Sumner RD, Ryan TJ, et al: Herniation of mitral leaflets in Ehlers-Danlos syndrome. Am J Cardiol 1975;36:524-528.

12. Bontempo CP, Ronan JA Jr, de Leon AC Jr, et al: Radiographic appearance of the thorax in systolic click-late systolic murmur syndrome. Am J Cardiol 1975;36:27-31.

13. Davies MK, Mackintosh D, Clayton RM, et al: Straight back: Mitral valve prolapse syndrome. $Q J$ Med, 1980;196:443-460.

14. Smith MK, Kavey RE, Lubicky, JP: Idiopathic scoliosis and mitral valve prolapse. J Fam Pract 1984;19:229-233.

15. Pickering NJ, Brody JI, Barrett MJ: von Willebrand syndromes and mitral-valve prolapse: Linked mesenchymal dysplasias. $N$ Engl $\mathrm{J}$ Med $1981 ; 305: 131-134$

16. Yoshimitsu Y, Eiji O, Nagai T, et al: The causative mechanisms of MVP in progressive muscular dystrophy in reference to thorax and thoracic spine deformities and left ventricular dysfunction. Jpn Circ $J$ 1984;48:321-327.

17. Mitral ballooning: A possible mechanism of mitral insufficiency in diseases associated with reduced end-systolic volume of the left ventricle, editorial. Chest 1971:60:114-115.

18. Wood SJ, Thomas J, Braimbridge M: Mitral valve disease and open heart surgery in osteogenesis imperfecta tarda. Br Heart $J$ 1973;35:103106.

19. Lebwohl MG, Distefano D, Prioleau P, et al: Pseudoxanthoma elasticum and mitral valve prolapse. $N$ Engl $J$ Med 1982;307:228-231

20. Garcia-Dorado D, Garcia EJ, Bello L, et al: Mitral valve prolapse secondary to right ventricular enlargement in patients with pulmonary hypertension after toxic rapeseed oil ingestion. Eur Heart $J$ 1985;6:8590.

21. Rosenberg CA, Derman GH, Grabb WC, et al: Hypomastia and mitralvalve prolapse: Evidence of a linked embryologic and mesenchymal dysplasia. N Engl J Med 1983;309:1230-1232.

22. Tay, JS, Yip WC, Yap HK, et al: Dermatoglyphs in children with mitral valve prolapse. $J$ Med Genet 1985;22:135-136.

23. Swartz, H: Dermatoglyphic patterns in patients with mitral valve prolapse: A clue to pathogenesis. Am J Cardiol 1976;38:588-593.

24. Kramer-Fox RB, Devereux RB, Brown WT, et al: Lack of association between dermal arches and mitral valve prolapse: Relation to anxiety. Am J Cardiol 1984;53:148-152.

25. Greenwood R: Mital valve prolapse: Clinical spectrum of 125 patients referred to a cardiac center. Pediatrics 1984;23:659-660.

Dr Kule, director of medical education at Massapequa General Hospital, Seaford, New York, was senior advisor for Dr Siebert at the time this paper was written.

Reprint requests to Dr Siebert, 79-21 Metropolitan Ave, Middle Village, NY 11379. 